\title{
The Contribution of Root and Tuber Crops to Food
}

\section{Security: A Review}

\author{
Karya Kate Nanbol and Otsanjugu Aku Timothy Namo \\ Department of Plant Science and Biotechnology, University of Jos, P.M.B. 2084, Jos, Plateau State, Nigeria
}

\begin{abstract}
Nigeria is a country endowed with enormous food and agricultural resources such as yam, cassava, cocoa, rice, sugar cane, maize and millet. In the early years of Nigeria's independence, cash crops such as rubber, cashew, groundnut and oil palm were the major crops around which the economy revolved. Today, there is a shift to alternatives for biofuel, pharmaceutical starch and derivatives using root and tuber crops, which have continued to play a significant role in the agricultural revolution of the country. The current agricultural transformation agenda in Nigeria is intended to engineer the bulk of root and tuber crops in the country into value-added products to match the increasing new tastes and demands for products across the globe. It is also intended to provide job opportunities and to generate additional income for low-income earners, especially in the rural areas. There is, therefore, the need to intensify research efforts aimed at exploring the potentials of major and minor root and tuber crops to ensure food security. In this review, six (6) major root and tuber crops, namely cassava (Manihot esculenta Crantz), yam (Dioscorea spp.), sweet potato (Ipomoea batatas (L.) Lam), potato (Solanum tuberosum L.), cocoyam (Xanthosoma sagittifolium Schott) and ginger (Zingiber officinale L.) as well as three (3) minor ones, namely the Hausa potato (Solenostemon rotundifolius (Poir) J. K. Morton), Livingstone potato (Plectranthus esculentus N.E.Br.) and the Polynesian arrowroot (Tacca leontopetaloides (L.) Kuntze) were examined. In spite of the numerous benefits derivable from these crops in terms of nutrition and medicinal values, some have been neglected to the extent that they are classified as orphan crops. Therefore, much more attention should be accorded to these crops, which have the potentials to contribute to food security in Nigeria.
\end{abstract}

Key words: Food security, root crop, tuber crop, review.

\section{Introduction}

Nigeria is an agrarian country that is endowed with enormous food and agricultural resources such as yam, cocoa, cassava, rice, sugar cane, maize and millet, as far back as the 1940s and 1950s. Then, the country did not have to contend with the problem of food insecurity. During this period, food produced in Nigeria was not only enough to feed her citizens, but the surplus was exported. Nigeria was relatively self-sufficient in food production.

A recent report from the Consultative Group on International Agricultural Research (CGIAR) notes that: "root crops will be many things to many people by 2020" [1]. Driving the author to this conclusion is the adaptation of root crops to marginal environments,

Corresponding author: Otsanjugu Aku Timothy Namo, professor, research fields: root and tuber crops. their vital role in promoting food security at the household level and their flexibility in mixed-farming systems. Root and tuber crops are the second most important group of crop plants after the cereals (Table 1).

However, while the cereals contribute $49 \%$ energy towards global food security, the contribution of the tuber crops is only $5.4 \%$. The other main food groups that contribute towards this are: oils, $12.5 \%$; meat and eggs, 9.5\%; sugar, 9.0\%; fruits, 3.0\% [2]. Root and tuber crops are often preferred over cereals both by farmers and consumers and are an important component of programmes, policies and strategies aimed at improving the economic wellbeing of the rural populace [3].

In the early years of Nigeria's independence, cash crops such as cocoa, rubber, cashew, groundnut and oil palm were major crops around which the economy revolved, but today there is a shift to alternatives for 
Table 1 Contribution of major food crops towards global food security

\begin{tabular}{ll}
\hline Food class & Contribution to global food security (\%) \\
\hline Cereals & 49.0 \\
Tuber crops & 5.4 \\
Oils & 12.5 \\
Meat and eggs & 9.5 \\
Sugar & 9.0 \\
Fruits & 3.0 \\
\hline
\end{tabular}

Source: Food and Agriculture Organization [2].

biofuel, pharmaceutical starch and derivatives using root and tuber crops. Root and tuber crops have continued to play a significant role in the agricultural production and revolution in Nigeria. Nigeria is the largest producer of most of the root and tuber crops in the world with a yearly output of 45 million metric tons for cassava, 32 million metric tons for yam, 1.3 million metric tons for sweet potato, 0.731 million metric tons for potato, 5.0 million metric tons for cocoyam and 0.223 million metric tons for ginger. The growth rates of root and tuber crops show some upward improvement between $2 \%$ and $80 \%$ from 1975 to 2011 [2].

In Nigeria, ninety-five percent (95\%) of root and tuber crops produced is consumed internally in unprocessed forms; hence the country continues to import finished products such as starch, flour, sweeteners and adhesives that are made from root and tuber crops, which is unacceptable. The present agricultural transformation agenda on root and tuber crops is mainly to engineer the bulk of the root and tuber crops in the country into value-added products to match the increasing new tastes and needs for products of root and tuber crops across the globe. It is also intended to provide job opportunities and generate income for Nigerians. The potential demand of 250,000 tons per year for high quality cassava flour by local and foreign companies, and replacement of bread flour by $40 \%$ cassava flour can only be met by root and tuber crops [4]. Most crops used for human food, animal feed, religious, traditional and ceremonial events in sub-Saharan Africa centre on root and tuber crops.
Root crops are the edible energy-rich underground plant structures developed from modified roots while tuber crops are those crops in which the edible energy-rich storage organs develop wholly or partly from underground stems [5]. They are grown all over the sub-Saharan region of Africa all the year round. The major root crops are cassava and sweet potato while the major tuber crops are yam, cocoyam, potato and ginger, which are the most important food crops for direct human consumption in Africa. These crops are grown in different agro-ecologies and production systems, contributing to more than 240 million tons annually and covering about 23 million hectares. The aggregate value of yam, cassava, potato and sweet potato exceeds all other African staples, including cereal crops (cereals annually produced on average of 169 million tons on 108 million hectares of land) [6]. The minor root and tuber crops are Livingstone potato, Hausa potato and Polynesian arrowroot. The productivity and growth rate of root and tuber crops in Africa and especially Nigeria have been increasing tremendously for the past two and a half decades, although such increase has not been meeting with the rising food demand due to high population pressure and poor infrastructural facilities to accelerate processing into food forms. Contributors to this trend in food production include the root and tuber crops sector with increasing annual output and growth rates.

\subsection{Concept and Definition}

Roots and tubers are plants yielding starchy roots, tubers, rhizomes, corms and stems [2]. They are used mainly for human food (as such or in processed 
forms), for animal feed and for manufacturing starch, alcohol and fermented beverages including beer. Apart from their high water content (70\%-80\%), these crops contain mainly carbohydrate (largely starches that account for $16 \%-24 \%$ of their total weight). These commodities are grown mainly by small-scale farmers, and most yield more (in terms of calories per hectare per day) than other crops [7].

\subsection{Food Security}

According to Aidoo et al. [8], food security and insecurity are terms used to describe whether or not households have access to sufficient quality and quantity of food. Other researchers like Bickel et al. [9] and Smith and Subandoro [10] defined food security as a situation that exists when all people at all times have physical and social access to sufficient, safe and nutritious food that meets their dietary needs and food preferences for an active and healthy life.

The elements of food security include food availability, food accessibility, utilization and stability of access to food [11]. Food availability refers to the presence of food, produced by the consumers themselves or available in the markets for purchase at affordable prices. Food availability is achieved when a sufficient amount of food is constantly available for all members of the society $[8,12]$. In this regard, rural food production plays an important role in ensuring household food security. On the other hand, food accessibility is attained when households or individuals have adequate resources that enable them to obtain appropriate foods for a nutritious diet [13] whereas food utilization encompasses decisions on food demand and allocation within the household.

\subsection{Household Food Security}

A household is the basic residential unit in which economic production, consumption, inheritance, child-bearing and shelter are organized and carried out. A household is a group of individuals whose economic decision-making is interrelated. The concept of household food security is a more recent development and the bulk of literature dated from 1980s equating national food security with food self-sufficiency is a problem that needs to be clearly understood.

\subsection{Food Insecurity}

Food insecurity is a situation when people lack secured access to sufficient amounts of safe and nutritious food required for normal growth and development as well as an active and healthy life. It may be caused by the unavailability of food, insufficient purchasing power, inappropriate distribution, or inadequate use of food at the household level [14].

\subsection{Conceptual Framework}

Food security is a broad and complex concept, determined by a range of factors-agro-ecological, socio-economic and bio-physical. Thus, there is no single and direct measure of food security. Conceptually, food security is divided into three distinct pillars or dimensions: food availability, access and utilization. According to the definition, household food security could be achieved by increasing agricultural productivity, raising household income and improving household nutrition. Using the aforementioned pillars, it is possible to define the contribution of root crops to the household food security.

Food availability refers to the availability of sufficient quantities and appropriate quality of food to household, supplied through domestic production (this includes crop and livestock), purchase or food aid. Food access refers to adequate resource entitlement to individuals to acquire appropriate foods for a nutritious diet. "Entitlements" are defined as the set of all commodity bundles over which a person can establish command, given the legal, political, economic and social arrangements of the community in which they live. Normally, food can be accessed 
through a combination of home production, stocks, purchase, gift, borrowing or food aid. It could also be ensured when communities, households and all individuals within them have adequate resources, such as money, to obtain appropriate foods for a nutritious diet. Food utilization is defined as the means by which individuals reach a state of nutritional well-being where all physiological needs are met. The pillar also includes clean water, sanitation, health care and adequate diet. It also depicts the importance of non-food inputs into food security including knowledge of dietary needs and their potential impact on human health [2].

\subsection{Food Security in Nigeria}

Nigeria, blessed as it is, with abundant agro-ecological resources and diversity, has become one of the largest food importers in sub-Saharan Africa [15]. Reducing food insecurity continues to be a major public policy challenge in developing countries. Almost one billion people worldwide are undernourished, many more suffer from micronutrient deficiencies, and the absolute numbers tend to increase further, especially in sub-Saharan Africa [16]. Olayide [17] conceived the food and nutrition problem in terms of food supply and demand imbalance. Factors that constrain food supply and food demand invariably affect food security. On the supply side, major factors hampering the supply of food in Nigeria are ownership of productive assets and resources which are biased against agricultural producers, nature of farm organization and technology which are crude and undeveloped, and the lack or primitive state of marketing infrastructures and mechanisms, all of which influence food output and availability.

Chronic food insecurity is the consequence of several long-term contributing factors [18] such as poverty, large variations in annual and seasonal precipitation, water shortage for people, crops and livestock, high population density in the highlands and midlands, environmental degradation, lack of education, lack of alternative employment opportunities in rural areas, lack of productivity-enhancing products, high business costs due to bad infrastructure and inefficient markets and high levels of infant and maternal malnutrition (contributing factor of disease and mortality) [19]. Despite efforts to improve food production through increased use of chemical fertilizers and improved seeds, notable improvement in national food production has not yet been achieved. At the national level, the country continues to depend on food aid and on food imports [19].

\section{Major Root and Tuber Crops}

\subsection{Major Root Crops}

\subsubsection{Cassava}

Cassava (Manihot esculenta Crantz) is a major food crop in sub-Saharan Africa. It is primarily a root crop, but the leaves and shoots, which are relatively high in protein, are also often eaten. The roots are an important calorie provider; more than 200 million people in sub-Saharan Africa (about one-third of the population) get more than half of their calories from foods made from cassava roots. A number of characteristics like famine-secure, drought-tolerance, ability to grow on poor soil, relative insect and pest resistance, more production of carbohydrate per hectare than other food staples and ability to be left in the ground for a long time before harvesting, made the crop encouragingly selectable by the small-scale farmers [20, 21]. During times of social and political unrest, when people are forced to farm marginal lands, cassava has proved to be an invaluable food-security crop. Cassava is also becoming a major source of income for smallholder farmers and of raw materials for local industries [22, 23].

Cassava as a food-security crop has played important roles in many households. It derives its importance from the fact that it is starchy and a cheap source of carbohydrate; more so, its tuberous roots are a valuable source of cheap calories especially in 
developing countries where calorie deficiency and malnutrition are widespread. Over two-thirds of the total production of cassava is consumed in various forms by humans. Cassava provides about $45 \%$ of all calories consumed in Africa [24] and about $70 \%$ of the daily calorie intake of over 50 million Nigerians. Cassava has advantage over other crops when compared; it generates income for the largest number of households [25]. Most households grow cassava as their main staple food, because tree crop production requires peak labour input mainly at planting and harvesting season while cassava production does not require such seasonal labour. Cassava roots are boiled and eaten without further processing. It has many alternative uses; the roots of sweet cassava varieties are eaten raw, roasted in an open fire, or boiled in water. Boiled roots maybe pounded alone or in combination with other starchy staples.

\subsubsection{Sweet Potato}

Sweet potato (Ipomoea batatas (L.) Lam.) is a dicotyledonous plant that belongs to the morning glory family, Convolvulaceae. Sweet potato is a root vegetable with roots that are sweet-tasting, starchy and tuberous. It is native to the tropical regions in America [26]. The plant is a herbaceous perennial vine, bearing alternate heart-shaped or palmately lobed leaves and medium-sized sympetalous flowers. The edible tuberous root is long and tapered, with a smooth skin whose colour ranges between yellow, orange, red, brown, purple and beige. Its flesh ranges from beige through white, red, pink, violet, yellow, orange and purple.

Sweet potatoes are grown in all parts of the country in diverse agro-ecological zones, from the tropical rainforest to semi-arid and arid zones. Planting begins at the onset of the rainy season and continues until two months before rains stop. Sweet potatoes may be planted on mounds, ridges, beds or on flat ground. The crop performs best on mounds and poorest on flat ground [27].Vines serve as planting materials and harvesting occurs 3-8 months after planting, depending on the variety. Harvesting entails cutting off shoots, carefully digging out tubers while avoiding bruises, using a fork shovel, long wooden sticks, metal rod with flattened ends or hoes. Estimated yields in the research fields varied from $40 \mathrm{t} / \mathrm{ha}$ to $70 \mathrm{t} / \mathrm{ha}$ for improved varieties, while in multi-locational trials yield averaged $23.5 \mathrm{t} / \mathrm{ha}$ across seasons and locations [26].

While the crop is considered a cash crop in certain parts of Nigeria, in most areas, sweet potato is grown as a secondary crop. Sweet potatoes are a staple crop in Northern Nigeria where they are mostly produced [28]. Sweet potato varieties with white or pale-yellow flesh are less sweet and moister than those with red, pink or orange flesh [27]. Orange-fleshed sweet potato roots have a nutritional advantage over white or cream-fleshed sweet potato roots because their beta-carotene and, therefore, vitamin A content are higher. This is evidenced by the deep orange colour of the sweet potato flesh, which is related to the higher beta-carotene and vitamin A content [29]. Orange-fleshed sweet potato roots are nutritious for many reasons. In addition to providing high levels of vitamin $A$, it contains high levels of vitamins $B, C, E$ and $\mathrm{K}$, all of which help protect the human body and assist in the recovery process from illness. Orange-fleshed sweet potato roots also have high carbohydrate content, allowing them to produce more edible energy per hectare per day than other common sources of carbohydrates such as rice and maize [29]. The use of orange-fleshed sweet potato genotypes possessing higher yields could improve the socio-economic conditions of the farmers as well as their nutritional status [30].

\subsection{Major Tuber Crops}

\subsubsection{Cocoyam}

Cocoyam (Xanthosoma sagittifolium Schott) is among the world's six most important root and tuber crops [31]. It is pan tropical and has been domesticated in most communities in Oceania, Africa 
and Asia [32] providing sustenance for over 400 million people [33, 34]. Africa is the major producer with West and Central Africa, notably Nigeria, Ghana and Cameroon contributing to over $60 \%$ of the total African production [35].

Generally, all plant parts (cormels, petioles, leaves and inflorescence) of cocoyam are edible [34, 36]. The wide distribution of the crop in different geographical areas and cultures has resulted in varying usage of the crop from one location to another [34]. They are mainly used as food in cultivated areas and the plant parts are also used as fodder/feed and medicine, including its use as anti-poisonous agents against tarantula, scorpion and snake bites. In its application as food, none of the plant parts is consumed raw because of its acridity [32]. Thus, most traditional cooking methods employ heat by boiling, baking, roasting or frying either alone or in combination with other ingredients to obtain delicacies [37, 38]. These may be snacks, main meals or special dishes for vulnerable groups. In West Africa, there are significant similarities in the use of indigenous root and tuber crops [39]. Only a handful of traditional dishes are popular across the major cocoyam-producing countries of Ghana, Nigeria, Cameroon and Cote d'Ivoire with Ghana dominating in diversity of indigenous cocoyam dishes.

The importance of cocoyam to regional food security cannot be overstated. Malnutrition is a major challenge to the growth and productivity of tropical developing economies where most staples are carbohydrate-rich but deficient in micronutrients. Cocoyam is postulated to have superior nutritional value over other major root and tuber staples of West Africa, especially in terms of their protein digestibility and mineral composition (calcium, phosphorus and magnesium) [37, 38, 40, 41]. According to Opara [37], $X$. sagittifolium can generally be regarded as an appreciable (middle range) source of dietary energy, proteins and vitamins. It is said to be high in potassium, zinc and nicotinic acid, in addition to being a low inhibitor of trypsin compared to other edible aroids.

\subsubsection{Potato}

Potato (Solanum tuberosum L.) popularly known as "the king of vegetables", has emerged as the fourth most important food crop after rice, wheat and maize. Potato is a nutritionally superior vegetable due to its edible energy and protein. It has become an integral part of breakfast, lunch and dinner among the larger populations. Being a short duration crop, it produces more quantity of dry matter, edible energy and edible protein in a lesser duration of time compared with cereals like rice and wheat. Hence, potato is considered to be an important crop to achieve nutritional security of the nation [42].

Potato is a major food crop, grown in more than 100 countries in the world. According to Food and Agriculture Organization [16], potato is consumed by more than one billion people in the world. It is a high quality vegetable cum food crop and is used in preparing more than 100 types of recipes. Besides being an important nutrient-dense food, potato is an efficient producer of food energy and nutrition per unit area and must figure prominently in combating any world food crises. Recent data indicate that potato has $75 \%$ more food energy per unit area than wheat and $58 \%$ more than rice. Also, potato has 54\% more protein per unit area than wheat and $78 \%$ higher than rice. In fact, no other food can match the potato in its production of food energy and food value per unit area. Nutritionally, potato is considered to be a well-balanced major plant food with a good ratio between protein and calories and has a substantial amount of vitamins, especially vitamin C, minerals and trace elements. Due to its correct balance between protein and calories, it is considered as a good weaning food [43]. The protein content of potato has a higher biological value than cereals and is considered as to be better than milk. Hence, potato is supplementing meat and milk products by lowering energy intake and also by reducing food cost. 


\subsubsection{Yam}

Yams (Dioscorea spp) are annual root tuber-bearing plants with more than 600 species out of which six are socially and economically important in terms of food, cash and medicine [44]. Some of these species are water yam (D. alata), white yam (D. rotundata), yellow yam (D. cayanensis) and bitter yam (D. dumetorum) [45, 46]. As a staple food crop, yam is grown in tropical regions [47] and mostly produced in the savannah region of West Africa, where rainfalls are divided into wet and dry seasons [48, 49]. Yams are the fifth most harvested crop in Nigeria, following cassava, maize, guinea corn and beans/cowpeas. Moreover, after cassava, yams are the most commonly harvested tuber crops in the country [50].

In West Africa, yam is a food and cash crop; it plays an important role in food security and in the livelihoods of 60 million people in the region. The crop is cultivated mostly in the derived, humid and Southern Guinea savanna agro-ecologies. About 48 million tons of yams (95\% of global supply) are produced on 4 million hectares annually in the region, mainly in five countries of Benin, Côte d'Ivoire, Ghana, Nigeria and Togo. Nigeria alone accounts for $70 \%$ of global yam supply [6]. In Ghana, $26.2 \%$ of the population depends on yam for income and food security. Yams are composed of water (0.5\%-75\%), fat $(0.7 \%-2.0 \%)$ and protein (1\%-25\%). Tubers contain some chemical constituents like good amounts of anti-oxidant, vitamin C, which plays an important role in anti-aging and collagen formation. They also contain appreciable amounts of protein, fat, carbohydrate, calcium, phosphate, iron and vitamin A which improve vision, health of skin, hair and bones. According to Nya et al. [51], yam peels are rich in nutrients which could be included in the daily dietary pattern of humans and could also help in minimizing the risk of nutrient deficiency in the consumers. The by-products also contain important phytochemicals needed to combat various kinds of infections in humans.

\subsubsection{Ginger}

Ginger (Zingiber officinale L.) is a flowering plant in the family Zingiberaceae. It is a root crop and a typical herb extensively grown across the world for its pungent aromatic under-ground stem or rhizome which makes it an important export commodity in world trade [52, 53]. The origin of ginger is not well established though it is generally thought to be a native of Asia, where it was first cultivated. It was also cultivated in the tropical regions of America. Ginger was introduced to Europe by Arab traders from India in the first century AD. The Arabs also took the plant from India to East Africa in the thirteenth century. The Portuguese took it to West Africa and other parts of the tropics in the sixteenth century. Ginger was introduced to Nigeria in 1927. The crop is now cultivated in different parts of Nigeria, though the major producing areas include Kaduna, Nasarawa, Sokoto, Zamfara, Akwa-Ibom, Oyo, Abia and Lagos states. However, the southern part of Kaduna State is the largest producer of ginger in Nigeria with concentrations in Kachia, Jaba, Jamma'a and Kagarko local government areas [54, 55]. Generally, the varieties produced in Nigeria especially in the southern part of Kaduna State are "Tafin Giwa” and "Yatsun Biri" which are higher in monoterpene and oil, giving a more pungent aroma. These species are usually preferred for the production of oils and oleoresins [54].

Ginger is commonly used for different purposes which include treatment of various types of illness like stomach upset, diarrhoea, morning sickness, nausea, vomiting and chemotherapy. Ginger is also used as tea and for making ginger juice. Dry powdered ginger can be used for food flavouring and in food processing industries [56]. Ginger is a high value cash crop that is grown by farmers in many parts of the world. Nigeria is known to be one of the major producers of ginger in the world [53]. The cultivation of ginger began in Nigeria when it was identified as 
one of the crops that could generate income and promote internal trade. In recent years, interest and demand for ginger have increased dramatically worldwide and the crop has assumed great importance in the global market [57].

\section{Minor Root and Tuber Crops}

\subsection{The Hausa Potato}

The Hausa potato (Solenostemon rotundifolius (Poir) J. K. Morton) is a minor tuber crop in most parts of Africa. On the world scale, the crop is the most widespread of the cultivated Lamiatae and is believed to be of economic importance [58]. The Hausa potato is a small herb that has prostrate or ascending succulent stems and branches. It attains a height of $15-30 \mathrm{~cm}$ and presents a distinctive fragrance due to the presence of volatile oils in the glands or sacs of leaves. The flowers are small and may be white, blue, pinkish or pale-violet in colour. They are borne on distal inflorescences with slender false spikes measuring up to $15 \mathrm{~cm}$ in length. It has small dark-brown edible tubers produced at the base [3].

It grows well in regions receiving an annual rainfall of between $700 \mathrm{~mm}$ and 1,000 $\mathrm{mm}$ [3, 59]. Yields under favorable condition may reach $18 \mathrm{t} / \mathrm{ha}$ to $45 \mathrm{t} / \mathrm{ha}$ [58]. In ethno-botany, the preparation of boiled leaves of the Hausa potato is used to treat such disorders as dysentery, blood in urine and eye disorders including glaucoma [60]. Tubers of the crop provide essential dietary and energy requirements to the populace during lean periods. The tubers taste similar to Irish potato and trifoliate yam and can be eaten as the main starchy staple or part of it in combination with legumes, rice and vegetables.

It is an important foodstuff both for rural and urban communities and helps to supplement tuber requirement in family menus [61]. It is a food source for the people during the period of food scarcity [62]. It possesses elite flavour and taste and has medicinal properties due to the presence of flavonoids that help to lower the cholesterol level of the blood. A considerable proportion of the Hausa potato as a staple foodstuff in the tropics has been largely replaced by other starchy foodstuffs such as sweet potatoes, and production has declined to such an extent that it has almost disappeared in many areas [62, 63]. Generally, the Hausa potato is a relatively under-exploited food crop in Nigeria.

\subsection{Livingstone Potato}

Livingstone potato (Plectranthus esculentus N.E.Br.) is a perennial herb with prostrate or ascending habits. It grows about $1 \mathrm{~m}$ high. The leaves form in opposite pairs or whorls at intervals along the stem. The stem is succulent and is covered in white hairs with lateral, trailing branches that root at the nodes. The flower is small about $1.5 \mathrm{~cm}$ long and bilaterally symmetrical with united petals and a four-lobed ovary that produces four one-seeded nutlets. The shallow, fibrous root system produces tubers that are dark-brown or black in colour and form in clusters around the base of the stem. The tubers are roughly cylindrical, up to $2 \mathrm{~cm}$ in diameter and 5-10 cm long (some as long as $25 \mathrm{~cm}$ ) [3].

Recent studies on the nutritional value of $P$. esculentus in South Africa recorded (on a dry-weight basis) $81 \%$ carbohydrate, $13.5 \%$ crude protein, $4 \%$ ash and $1 \%$ fat. In addition, the tuber material contained (in mg per $100 \mathrm{~g}$ of plant material) vitamin A (0.2), thiamin (0.04), riboflavin (0.06), vitamin B6 (0.3), phosphorus (337), potassium (1,721), calcium (140), magnesium (327), zinc (3.5), copper (1), manganese (1.4), sodium (73) and iron (50) [64].

\subsection{Polynesian Potato}

The Polynesian arrowroot (Tacca leontopetaloides) is a wild plant in Nigeria known to have been domesticated in the Pacific Island nations [65]. The underground tubers are relatively hard and potato-like. Polynesian arrowroot contains $10 \%-25 \%$ of starch, and they serve as an important food source for many Pacific Island cultures, especially amongst the inhabitants of 
Low Island. Recent studies have demonstrated a close taxonomic family relationship between the local cherished food yams (Dioscorea spp) and the Taccaceae (now Tacca) genera that include Polynesian arrowroot. Polynesian arrowroot is indigenous to Nigeria based on the abundance of wild species and very large diversities that are found in Plateau and Nasarawa states. In areas where Polynesian arrowroots are used, almost all the varieties are used as a delicacy for newly wedded couples. The medicinal value of taccalin found in the tubers as well as the seeds and cherished by birds needs further investigation. In Northern Nigeria, the tubers are processed for food and are also used to treat stomach disorders, diarrhoea and dysentery [66]. The root is mashed and put topically on guinea-worm infected parts of the body and is also taken as infusion to treat hepatitis [65]. In Plateau State, the root preparation is used for treating snake bite and infection [67].

In spite of its importance as a food source in Nigeria [68], as a starch in stiffening fabrics and as a panacea in the treatment of diarrhoea and dysentery [69], Polynesian arrowroot (locally known as "Amora") is still a wild plant in Nigeria [66]. There is insufficient knowledge on the way it should be grown, the optimum spacing required for the growth of the crop as well as the quantity and type of fertilizer required. Major constraint facing farmers wishing to grow Polynesian arrowroot and many other indigenous crops is lack of scientific information. Because the rains nowadays are unpredictable, unreliable and highly vulnerable to the vagaries of weather, the demand for food in Nigeria always exceeds its supply [67]. Indigenous crops can withstand the effect of drought and weather stress, thereby increasing the quantity of food production.

\section{Root and Tuber Crop Production and Marketing}

\subsection{Root and Tuber Crop Production}

Root crops are grown in a wide area and in different agro-climatic zones of the country. For instance, sweet potato is one of the major root crops widely grown in Nigeria. The production of sweet potato has expanded in the last decade to almost all ecological zones in Nigeria [70]. Presently, 381,000-510,000 ha of land are subjected to sweet potato cultivation in Nigeria with an annual production figure of 3.46 million metric tons [70].

Cassava is one of the world's most important food crops, with an annual global production of approximately 276 million metric tons. In 2013, the top producing countries were Nigeria, Thailand, Indonesia, Brazil and the Democratic Republic of Congo (Table 2).

Global demand for the commodity has been growing significantly between 2004 and 2013 because of its appeal as a food security crop for growing populations in emerging markets and the growing demand for industrially processed cassava products. Africa accounts for less than $1 \%$ of total exports and the cassava production space is dominated by smallholder farmers (25\% women). The root crop is a source of livelihood for at least 300 million people. Virtually all cassava (90\%) produced in Africa is used as a staple food for human consumption, providing calories for about 500 million people and constituting

Table 2 Top cassava-producing countries and percentage contribution in 2013.

\begin{tabular}{ll}
\hline Country & Percentage of total world production (\%) \\
\hline Nigeria & 13 \\
Thailand & 11 \\
Indonesia & 9 \\
Brazil & 8 \\
The Democratic Republic of Congo & 6 \\
\hline
\end{tabular}

Source: International Institute of Tropical Agriculture [71]. 
about $37 \%$ of the population's dietary energy requirements [71].

\subsection{Root Crop Marketing}

The important market places for buyers to sell these commodities are village markets within the area of production. Markets outside of the village and city markets are rarely used by producers. This implies that market interventions to improve the gains to producers need to target village level markets [72]. The major constraints of marketing include lack of markets to absorb the production, low price for the products, large number of middlemen in the marketing system, inability of marketing institutions to safeguard farmers' interest and rights over their marketable produce (e.g., cooperatives), lack of coordination among producers to increase their bargaining power, poor product-handling and packaging, imperfect pricing system and lack of transparency in market information system mainly in the export market [43].

\section{Importance of Root and Tuber Crops}

The potentials of root and tuber crops in the Agricultural Transformation Agenda cannot be overemphasized. Root and tuber crops have the complimentary capacity to key into the existing government action plan of diversifying the economy of Nigeria. This will drive the economy into a multi-faceted structure in addition to petroleum resources. The economic importance of root and tuber crops in the overall economy of the sub-Saharan countries cannot be over-emphasized. Yam, cassava, potato, ginger, cocoyam, sweet potato and minor root and tuber crops (Hausa potato, Polynesian arrowroot and Livingstone potato (Rizga), etc.) play vital roles in the food basket of the world. Apart from being principal food sources, they constitute the single most important occupational group in Nigeria. Root and tuber crops generate income for Nigeria. Food crops such as cassava and yam contribute about $40 \%$ of household income with the recent development and release of provitamin A cassava varieties, TMS 03/1368, 1371, 1412 and NRCRI 2011. The nutritional status of resource-poor farmers is likely to improve with increased consumption of provitamin A cassava varieties and the rate of malnutrition is likely to decline in Nigeria.

The importance of root and tuber crops as staple foods is linked to particular agronomic advantages: they are well adapted to diverse soil and environmental conditions and a wide variety of farming systems. They are also a highly efficient source of edible carbohydrates when compared with other food crops. With diversification of conducive agro-ecologies that enable all-year round production, reliable water source, increasing demand and price of products with increase in population, urbanization, and awareness of consumers and price increase in animal products, the demand and hence the price for root crops in general are increasing. Better infrastructure (roads and telecommunication), cheap labour force and conductive agricultural development policies are the opportunities available in the country [73].

\section{Conclusions}

The major root and tuber crops that are used as staple or secondary staple foods are cassava, sweet potato, cocoyam, yam, potato and ginger. The minor ones include the Polynesian arrowroot, Hausa potato and Livingstone potato. Presently, all the root and tuber crops together contribute $5.4 \%$ of the total energy needs of the humans from $61.1 \mathrm{~kg}$ tubers per head annually. Of this amount, the tuber crops alone contribute 3.9\% energy for an average consumption of $28.6 \mathrm{~kg} / \mathrm{capita} /$ year (76 $\mathrm{kcal} /$ capita/day). It is estimated that this contribution will be doubled to $8 \%$ by 2030. This has become imperative in view of the emerging food crisis and the on-going changes in climate with the attendant problems of temperature rise, increasing drought, sea level rise and the unpredictable spurt in extreme environmental 
variations. In this scenario, the innate advantages and climate resilience of root and tuber crops to such extreme and unpredictable variations are recognized. Cassava and yams in particular are resistant to temperature stress. Root and tuber crops have a great potential for contributing to food security. Their production and utilization should, therefore, be encouraged.

\section{References}

[1] Scott, G. J., Best, M. R., and Bokanga, M. 2000. Roots and Tubers in the Global Food System: A Vision Statement to the Year 2020. Lima: International Potato Centre (CIP), 274.

[2] Food and Agriculture Organization. 2009. Production Year Book for 2009. Rome, Italy: Food and Agriculture Organization.

[3] National Research Council. 2006. Lost Crops of Africa: Vegetables. Vol. 11. Washington, DC: The National Academies Press. doi: 10.17226/11763.

[4] Oke-Okoro, O. N., Njoku, D. N., Mbe, J. O., Awah, J. I., Amanze, N. J., and Oke-Okoro, O. C. 2014. "Contribution of Root and Tuber Crops in the Agricultural Transformation Agenda in Nigeria.” APRP Journal of Agricultural and Biological Science 9 (8): 276-83.

[5] Okunneye, P. A. 2002. "Rising Cost of Food Prices and Food Insecurity in Nigeria and Its Implication for Poverty Reduction.” Economic and Financial Review 40: 6-12.

[6] Nteranya, S. 2015. "Root and Tuber Crops.” In Feed Africa: An Action for African Agricultural Transformation. Senegal, Dakar, 26.

[7] Christopher, N. 1995. Adding Value to Root and Tuber Crops: A Manual on Product Development. Cali, Colombia: Centro International de Agricultural Tropical, 166.

[8] Aidoo, R., Mensah, J. O., and Tuff, T. 2013. "Determinants of Household Food Security in the Sekyere-Afram Plains District of Ghana.” In Proceedings of the 1st Annual International Interdisciplinary Conference (AIIC), April 24-26, 2013, Azores, Portugal.

[9] Bickel, G., Nord, M., Price, C., Hamilton, W., and Cook, J. 2000. Guide to Measuring Household Food Security. Alexandria: Department of Agriculture, Food and Nutrition Service.

[10] Smith, L. C., and Subandoro, A. 2007. "Measuring Food Security Using Household Expenditure Surveys." International Food Policy Res. Inst. Laxenburg, Austria, Commission on Sustainable Development (CSD). CSD-16 Review Session 5-16 May, 2008 United Nations,
New York.

[11] Bonnard, P. 1999. "Increasing the Nutritional Impact of Agricultural Interventions.” Presented at the Greater Horn of Africa Regional Workshop: Agricultural Policy, Resource Access and Human Nutrition, Addis Ababa, Ethiopia.

[12] Henri-Ukoha, A., Ibekwe, U. C., Chidiebere-Mark, N. M., and Ejike, R. O. 2013. "Determinants of Food Security in Female-Headed Households Involved in Individual Tenure System in Abia State, Southeast Nigeria.” Global Journal of Agricultural Research 1 (2): 48-57.

[13] USAID. 1992. Policy Determination 19: Definition of Food Security, April, 13, 1992, Washington D.C., 32.

[14] World Food Programme (WFP). 2004. "Global Food Security Update: Tracking Food Security Trends in Vulnerable Countries.” World Food Programme, Issue 13, February 2014.

[15] Idachaba, F. S. 2009. "The Looming Food Crisis." Newswatch, Lagos (August 3), Special Colloquium Edition.

[16] Food and Agriculture Organization. 2008. The State of Food Insecurity in the World. Rome, Italy: Food and Agriculture Organization.

[17] Olayide, S. O. 1982. "Food and Nutrition Crisis in Nigeria." International Journal of Food Nutrition and Safety 2 (2): 86-98.

[18] Riley, B., Church, P., Downer, G., Flaux, D., and Ulrich, P. 2002. "The Impact of the Title II Food Aid on Food Security in Ethiopia." United States Agency for International Development, Food and Humanitarian Affairs Office, USAID/Ethiopia.

[19] Walsund, E. 2011. "Food Security and Food Sufficiency in Ethiopia and Eastern Africa.” M.Sc. thesis, Lund University.

[20] Nweke, F. I., Spencer, D. S. C., and Lynam, J. K. 2002. The Cassava Transformation: Africa's 69 Best Kept Secrets. Lansing, Michigan: Michigan State University Press, 368.

[21] Roza, B. 2011. "Factors Influencing Micropropagation and Somatic Embryogenesis of Two, Kello and Qulle, Cassava Varieties.” M.Sc. thesis, Addis-Ababa University.

[22] Onabola, A. O., and Bokanga, M. 1998. "The Promotion of Cassava as a Food Industry: Case Study in Nigeria.” In Root Crops and Poverty Alleviation, edited by Akoroda, M. O., and Ekanaye, I. J., 293-6. Proceedings of the $6^{\text {th }}$ Triennial Symposium of the International Society for Tropical Root and Tuber Crops-Africa Branch (ISRTC-AB), October 22-28, 1995, Lilongwe, Malawi.

[23] Sanni, M. O., Sobamiwa, A. O., Rosling, H., and Eyinla, C. M. 1998. "The Importance of Cassava as Sustenance for Ibadan Small-Scale Garri Processors.” In Root Crops 
and Poverty Alleviation, edited by Akoroda, M. O., and Ekanaye, I. J., 290-2. Proceedings of the $6^{\text {th }}$ Triennial Symposium of the International Society for Tropical Root and Tuber Crops Africa Branch (ISRTC-AB), October 22-28, 1995, Lilongwe, Malawi.

[24] Nwajiuba, C. U. 1995. "Socio-Economic Impact of Cassava Post-harvest Technologies in Small Holders in South Eastern Nigeria.” Farming Systems and Resource Economics in the Tropics 20: 10-4.

[25] Food and Agriculture Organization. 2002. FAOSTAT-Data Base Result 228, Records of Sweet Potato Production, 2002-2004. Rome, Italy: Food and Agriculture Organization.

[26] Tewe, O. O., Ojeniyi, F. E., and Abu, O. A. 2003. Sweet Potato Production, Utilization and Marketing in Nigeria. Lima, Peru: International Potato Centre, 54.

[27] Gad, L., and George, T. 2009. The Sweet Potato. United States: Springer Publishing Company, 391-425.

[28] Amienyo, C. A., and Ataga, A. E. 2007. "Use of Indigenous Plant Extracts for the Protection of Mechanically Injured Sweet Potato (Ipomoea batatas (L.) Lam.) Tubers.” Scientific Research and Essay 2 (5): 167-70.

[29] Stathers, T., Benjamin, M., Katcher, H., Blakenship, J., and Low, J. 2013. "TOT Manual 2: Orange-Fleshed Sweet Potato and Nutrition.” In Everything You Ever Wanted to Know about Sweet Potato: Reaching Agents of Change. Nairobi, Kenya: International Potato Centre.

[30] Attaluri, S., Janardhan, K. V., and Light, A. 2010. "Sustainable Sweet Potato Production and Utilization in Orissa, India." In Proceedings of a Workshop and Training, Bhubaneswar, Orissa, India, Mar 17-18, 2010.

[31] Food and Agriculture Organization. 2012. Crop and Food Security Assessment Mission Ethiopia, Special Report.

[32] Ramanatha, R. V., Matthews, P. J., Eyzaguirre, P. B., and Hunter, D. 2010. The Global Diversity of Taro: Ethnobotany and Conservation. Rome, Italy: Biodiversity International.

[33] Onokpise, O. U., Wutoh, J. G., Ndzana, X., Tambong, J. T., Meboka, M. M., Sama, A. E., and Bruns, M. 1999. "Evaluation of Macao Cocoyam Germplasmin Cameroon.” In Perspectives on New Crops and New Uses, edited by Janick, J., Alexandria, VA: ASHS Press, 394-6.

[34] Vaneker, K., and Slaats, E. 2013. "Mapping Edible Aroids.” Iridescent Icograda 3: 34-45.

[35] Onyeka, J. 2014. "Status of Cocoyam (Colocasia esculenta and Xanthosoma spp.) in West and Central Africa: Production, Household Importance and the Threat from Leaf Blight.” CGIAR Research Program on Roots, Tubers and Bananas (RTB).

[36] C.A.B.I. 2014. "Invasive Species Compendium." Wallingford, UK: $\mathrm{CAB}$ International. http://www.cabi.org/isc/.

[37] Opara, L. U. 2003. Edible Aroids: Post-Harvest Operations. Rome, Italy: Food and Agriculture Organization of the United Nations.

[38] Lim, T. K. 2016. Edible Medicinal and Non-medicinal Plants, 1st ed. New York: Springer Publishing Company, 256.

[39] Falade, K. O., and Okafor, C. A. 2014. "Physicochemical Properties of Five Cocoyam (Colocasia esculenta and Xanthosoma sagittifolium) Starches.” Food Hydrocolloids 30: 173-81.

[40] Chukwu, G. O., Ekwe, K. C., and Anyaeche, S. 2008. “Cocoyam Production and Usage in Nigeria.” In National Root Crops Research Institute (NRCRI) News Bulletin, 1-2.

[41] Ekwe, K. C., Nwosu, K. I., and Nwachukwu, I. 2009. "Examining the Under-Exploited Values of Cocoyam (Colocasia and Xanthosoma spp.) for Enhanced Household Food Security, Nutrition and Economy in Nigeria.” Acta Horticulture 806: 71-8.

[42] Shrinivas, B. 2011. "Production, Processing and Marketing of Potato in Karnataka-An Economic Analysis.” M.Sc. thesis, University of Agricultural Sciences.

[43] Bezabih, E., and Mengistu, N. 2011. Potato Value Chain Analysis and Development in Ethiopia: Case of Tigray and SNPP Regions. International Potato Centre-Ethiopia, 88.

[44] International Institute of Tropical Agriculture. 2009. Yam (Dioscorea Species). IITA Publications.

[45] Ike, P. C., and Inoni, O. E. 2006. "Determinants of Yam Production and Economic Efficiency among Small-Holder Farmers in South-Eastern Nigeria.” Journal of Central European Agriculture 7 (2): 337-42.

[46] Zaknayiba, D. B., and Tanko, L. 2013. "Costs and Returns Analysis of Yam Production along Small Scale Farmers in Karu Local Government Area, Nasarawa State, Nigeria." Production Agriculture and Technology Journal 9 (1): 73-80.

[47] Thouvenel, J. C., and Fauquet, C. 1979. "Yam Mosaic: A New Potivirus Infecting Dioscorea cayanensis in the Ivory Coast.” Annals of Applied Biology 19: 279-83.

[48] Etejere, E. O., and Bhat, R. B. 1986. "Traditional and Modern Storage Methods of Underground Root and Stem Crops in Nigeria.” Turriaba 36 (1): 33-7.

[49] Food and Agriculture Organization. 1998. "Chapter 1-The Role of Roots and Tubers in Nutrition.” In Storage and Processing of Roots and Tubers in the Tropics. http://www.fao.org/3/X5415E/X5415E00.htm.

[50] National Bureau of Statistics. 2012. "LSMS: Integrated Surveys on Agriculture: General Household Survey Panel.” General Household Survey Panel, 2012-2013: 
Microdata Library.

[51] Nyam, M. A., Wonang, D. L., Nanbol, K. K., and Francisca, J. A. 2017. "Studies on Potentials and Fungal Spoilage of Two Species of Yam (Dioscorea dumetorum and Dioscorea cayenensis) Seeds Stored at Room Temperature in Jos, Nigeria.” Botany Journal 110: 154-60.

[52] Ndanmadu, J., and Marcus, P. L. 2013. "Efficiency of Ginger Production in Selected Local Government Areas of Kaduna State, Nigeria.” International Journal of Food and Agricultural Economics 1 (2): 39-52.

[53] Factfish, K. 2013. "World Ginger Production." www.factfish.com\%2F...\%2Fginger.\&oq.

[54] K.A.D.P. 2000. Production of Ginger: An Extension Guide. Kaduna State Agricultural Development Project, Kaduna.

[55] K.A.D.P.2004. Annual Report. Kaduna State Agricultural Development Project, Kaduna.

[56] National Bureau of Statistics. 2013. "National Survey on Agricultural Exportation Commodities.” Basic Information Document, General Household Survey Panel, 2013-2014.

[57] Egbuchua, C. N., and Enujeke, E. C. 2013. “Growth and Yield Responses of Ginger (Zingiber officinale) to Three Sources of Organic Manures in a Typical Rainforest Zone, Nigeria.” Journal of Horticulture and Forestry 5 (7): 109-14.

[58] Nkansah, G. O. 2004. "Solenostemon rotundifolius (Poir) J. K. Morton.” In Record from PROTA4U, edited by Grubben, G. J. H., and Denton, O. A. PROTA 2: Vegetables/Plant Resources of Tropical Africa, 204.

[59] Quedraogo, A., Sedego, A., and Zongo, J. D. 2007. "Farmers Perceptions of the Culture and Uses of the Fabirama (Solenostemon rotundifolius (Poir) J. K. Morton) in the Central Plateau of Burkina Faso.” Annual Botany Africa Quest 4:13-21. (in French)

[60] Schippers, R. R. 2000. African Indigenous Vegetables: An Overview of the Cultivated Species. Charham, UK: Natural Resources Institute/ACP-EU Technical Centre for Agricultural and Rural Cooperation, 83-9.

[61] Jada, M. Y., Bello, D., Leuro, J., and Jakusko, B. B. 2007. "Responses of Some Hausa Potato (Solenostemon rotundifolius (Poir) J. K. Morton) Cultivars to Root-Knot Nematode (Meloidogyne javanica) Chitwood in Nigeria.”
International Journal of Agriculture and Biology 9 (6): 948-50.

[62] Oteng-Yeboah, A. A., and Bennett-Lartey, S. O. 2008. "Ghana Country Report on the State of Plant Genetic Resources for Food and Agriculture.” In Second Report on the State of World's Plant Genetic Resources for Food and Agriculture Organization, 1-33.

[63] Dittoh, J. S., Bayorbor, T. B., Yidana, J. A., Abapol, R. R., and Otoo, J. A. 1998. "The Potential and Constraints of Persa (Frafra Potato) as a Food Security Crop in Northern Ghana.” In Proceedings of the 1st Biennial National Research Systems (NARS) Workshop, Accra International Conference Centre, 2-15.

[64] Allemann, J. 2002. "Evaluation of Plectranthus esculentus N.E.Br. as a Potential Vegetable Crop.” Ph.D. thesis, University of Pretoria.

[65] Kay, D. E., and Gooding, E. G. B. 1978. "Crops and Product Digest 2.” In Root Crops, $2^{\text {nd }}$ ed. London: Tropical Development and Research Institute, 308.

[66] Ukpabi, U. J. 2009. Cassava Processing and Utilization: Sensitization Book, 1st ed. Umudike, Nigeria: N.R.C.R.I, 520.

[67] Borokin,T. I., and Ayodele, A. E. 2012. "Phytochemical Screening of Tacca leontopetaloides (L.) Collection from Geographical Locations in Nigeria.” International Journal of Botany 2 (4): 97-102.

[68] Spennemann, D. H. R. 1994. "Traditional Arrowroot Production and Utilization in Marshall Islands.” Journal of Ethnobiology 14 (2): 211-34.

[69] John-Rey, F. 1997. "Cost-Benefit Analysis. Free Management Newsletter." In Native Plants Used as Medicine in Hawaii, 1-2.

[70] N.R.C.R.I. 2008. "National Root Crops Research Institute: Sweet Potato Programme.” Accessed October 6 ${ }^{\text {th }}, 2015$. http:// nrcri.gov.ng/index.php/sweetpotato-research.

[71] International Institute of Tropical Agriculture. 2015. Healthy Yam Seed Production. IITA Publications.

[72] Onubuogu, G. C., and Onyeneke, R. U. 2012. "Market Orientation of Root and Tuber Crops Production in Imo State.” Agricultural Science Research Journals 2 (5): 206-16.

[73] Getachew, T., and Mohammed, Y. 2012. Mapping the Current Knowledge of Carrot Cultivation in Ethiopia: Denmark, 20. 